TITLE:

\title{
Effect of propofol on androgen receptor activity in prostate cancer cells(Abstract_要旨)
}

\author{
$\operatorname{AUTHOR}(\mathrm{S}):$ \\ Tatsumi, Kenichiro
}

\section{CITATION:}

Tatsumi, Kenichiro. Effect of propofol on androgen receptor activity in prostate cancer cells. 京都大学, 2018, 博士(医学)

ISSUE DATE:

2018-03-26

URL:

https://doi.org/10.14989/doctor.k20970

RIGHT:

許諾条件により本文は2018-05-26に公開 


\begin{tabular}{|l|l|l|c|}
\hline 京都大学 & 博士 ( 医 学 $)$ & 氏 名 & 辰 巳 健 一 郎 \\
\hline 論文題目 & $\begin{array}{l}\text { Effect of propofol on androgen receptor activity in prostate cancer cells } \\
\text { (前立腺癌細胞におけるアンドロゲン受容体の転写活性に対するプロポフォ } \\
\text { ールの影響) }\end{array}$
\end{tabular}

(論文内容の要旨)

全身麻酔と悪性腫瘍の予後との関連について検討した臨床研究が増加してい る。腫瘍の再発に要する時間と比較すれば、麻酔薬に暴露されている時間はは るかに短いため、麻酔薬が予後に影響する可能性は一見低いように考えられる。 しかし、多くの臨床研究により麻酔薬を含む、体温、疼痛、炎症、心理的ス卜 レスなどが悪性腫瘍の術後再発に影響しうることが明らかとなってきた。近年、 前立腺癌は顕著な増加傾向にあり、その予後の改善に寄与する麻酔方法の確立 は臨床上重要な意義を有する。前立腺癌の特徵は、アンドロゲン依存性の増殖 を示すことであり、アンドロゲンと結合したアンドロゲン受容体（AR： androgen receptor）は核内一移行し、転写因子として増殖に必要な多数の遺伝 子を誘導することが知られている。今回、代表的全身麻酔薬であるプロポフォ 一ルが前立腺癌に及ぼす影響について、AR の転写活性に対する作用を中心に 検討した。

ヒト前立腺癌細胞株 $\mathrm{LNCaP}$ を用い、アンドロゲン (DHT： dihydrotestosterone）投与下での AR 標的遺伝子（PSA、FKBP5、TMPRSS2） の発現をリアルタイム RT-PCR 法により検討した。DHTによる AR 標的遺伝 子の誘導は、臨床使用濃度内のプロポフォール投与により有意に抑制された。 PSA タンパクの発現量も、プロポフォールにより有意に抑制された。LNCaP 細胞以外の前立腺癌細胞株 $(\mathrm{VCaP})$ においても、プロポフォールは $\mathrm{AR}$ 標的遺 伝子の誘導を有意に抑制した。また $\mathrm{LNCaP}$ 細胞の生存率を $\mathrm{MTT}$ 法で評価す ると、プロポフォールの 24 時間暴露により $\mathrm{LNCaP}$ 細胞の生存率は有意に減少 した。続いて、プロポフォールが AR の転写活性を抑制する機序について検討 した。イムノブロット法および免疫蛍光抗体染色法において、プロポフォール は AR タンパクの核における発現量を抑制した。一方、細胞全体での AR 発現 量はプロポフォールによって変化せず、プロポフォールは AR の核移行を抑制 することにより、ARの転写活性を抑制することが示唆された。最後に、AR 以 外の転写因子として低酸素誘導性因子（HIF： hypoxia-inducible factor） - 1 に ついても検討した。HIF-1 は低酸素下で活性化する転写因子で、前立腺癌の再 発や転移に関与寸ると報告されている。低酸素（1\%酸素）環境下で LNCaP 細 胞において誘導される HIF-1 活性に、プロポフォールが及ぼす影響を評価した。 低酸素下の HIF-1 タンパクの核内発現はプロポフォールにより有意に抑制さ れ、HIF-1 標的遺伝子の誘導も同様に抑制された。

これらの結果から、プロポフォールは前立腺癌細胞において AR の核移行を 阻害することによりアンドロゲン-AR 系の転写活性を抑制し、前立腺癌細胞の 増殖抑制作用を示すことが考えられた。また低酸素下での HIF-1の核移行もプ ロポフォールにより抑制された。AR、HIF-1 の核移行は微小管を介寸るとの報 告があり、プロポフォールは微小管依存性の輸送に作用することで、これら転 写因子の核内発現を抑制するのかもしれない。近年、全身麻酔が前立腺癌を含
む悪性腫瘍の予後に有意に影響しうるとの結果が集積しているが、今回の結果 からプロポフォールによる全身麻酔は、前立腺癌手術において患者予後を改善 寸る可能性があると考えられた。

\section{（論文審査の結果の要旨）}

アンドロゲン受容体は、前立腺癌細胞の増殖において中心的な役割を担う転写因子で あり、主に精巣から分泌されるアンドロゲン (DHT : dihydrotestosterone) と結合した後に 核内一移行し、増殖に必要な遺伝子を誘導する。本研究は、前立腺癌細胞において静脈 麻酔薬プロポフォールがアンドロゲン受容体の転写活性に及ぼす影響について検討した ものである。細胞株を用いた実験から、DHTによるアンドロゲン受容体標的遺伝子誘導 は、臨床使用濃度内のプロポフォールで抑制された。また培養液中の prostate-specific antigen (PSA) タンパクの発現もプロポフォールで抑制された。プロポフォール 24 時間暴 露は細胞増殖を抑制した。低酸素下で活性化する転写因子である低酸素誘導性因子 (HIF : hypoxia-inducible factor)-1 の発現は、癌の悪性度と関係する。プロポフォールは低 酸素下での HIF-1 標的遺伝子誘導を抑制した。また、アンドロゲン受容体および HIF-1 タンパクの核内発現はプロポフォールにより抑制された。本研究の結果は、プロポフォ ールがアンドロゲン受容体および HIF-1 の核移行を阻害し、再発・転移に関わるこれら 転写因子の活性化を抑制することを示唆する。

以上の研究はプロポフォールが前立腺癌細胞に及ぼ寸影響の解明に貢献し、麻酔科学 の発展に寄与するところが多い。

したがって、本論文は博士（医学）の学位論文として価值あるものと認める。

なお、本学位授与申請者は、平成 29 年 12 月 25 日実施の論文内容とそれに関連 した試問を受け、合格と認められたものである。

要旨公開可能日： 年 月 日 以降

